\title{
Gene Cluster Text Format
}

National Cancer Institute

\section{Source}

National Cancer Institute. Gene Cluster Text Format. NCI Thesaurus. Code C123891.

A tab delimited, matrix file text format that describes a gene expression dataset; the columns of the matrix correspond to profiles, the rows correspond to genes, and the values of the cells correspond to an expression measurement. 